\title{
The effect of freshwater
}

\section{acidification in the tissues of}

\section{Cyprinus carpio}

\author{
Ibrahim A ${ }^{1}$, Narayanan $\mathbf{M}^{2}$, Khan Salman ${ }^{1}$ and Sheik Mohamed ${ }^{3}$ \\ 'Department of Pathological Analysis, College of Health Science, Knowledge University, Erbil, Iraq \\ ${ }^{2}$ Aquatic Acidification Research Unit, Department of Zoology, St.Xavier's College, Palayamkottai, India \\ ${ }^{3}$ Marine Science Institute, University of Texas, Austin, USA
}

Received: 10 March, 2020

Accepted: 09 April, 2020

Published: 13 April, 2020

*Corresponding author: Ibrahim A, Department of Pathological Analysis, College of Health Science, Knowledge University, Erbil, Iraq,

E-mail: iformribrahim@gmail.com

Keywords: Low pH; Acidification; Fish (Cyprinus carpio); Histology; Liver; Gills; Intestine

https://www.peertechz.com

\section{Check for updates}

\begin{abstract}
The extant study was carried out to discern the effect of different acidic $\mathrm{pH}$ on the tissues of fishes. The experimental fish Cyprinus carpio were introduced into acidic waters ( $\mathrm{pH} 5.0 ; 5.8 ; 6.6$ and control 7.2) for 21 days for the histopathological exploration, the pH was upheld vigilantly throughout the investigation, after the experimental period, the results revealed the transfigures in the tissues of gills, intestine and liver. The annihilation of the epithelial layer with hypertrophy and hyperplasia in the gills and the development of necrotic gill disease, the fallouts from the intestine displayed the mucosal necrosis, and massive sloughing off mucosal epithelium, the liver unveiled the massive and intense granulomatous reaction and development of necrotic hepatitis.
\end{abstract}

\section{Introduction}

Histopathological analysis has been documented to be unswerving biomarkers of stress in fish [1]. Histopathological variations have been extensively utilized as biomarkers in the assessment of the healthiness of the fish, which introduced into contaminated habitat, both in the lab and ground studies. It is a great advantage to use the histopathological tissue identities in ecological monitoring and this type of biomarkers permits to analyse the tissues like the gills, kidney and liver; those are accountable for vibrant roles of respiration, excretion and the accretion and bioconversion in the fish [2]. Histology is a powerful technique to find effects of the hazardous substances in various tissues. The testing of fishes with the pollutants in the aquatic environment,which tempts to numerous tissue impairments. The respiratory structure (gills) is a compatible organ for the histopathological observations to conclude the consequences of environmental abnormalities. The gills of the fishes are engaging with the physiological functions of osmotic control, eliminating metabolic wastes and breathing. The gill tissues are observing the abnormal features of the waters. They are highly suitable for the evaluation of aquatic environmental influence [3.4]. Histopathological examinations are useful to observe the effect of the abnormal concentrations of pollutants on fishes in the biometrics $[5,6]$.
The effects of occasional $\mathrm{pH}$ decline and inorganic contaminants on aquatic animals are just recounted [7]. Protracted exposure to low $\mathrm{pH}$ can cause anomalous progress of laboratory nurtured fish [8-12]. In addition to variations in physiological performances, anatomical variations like abridged development [12-18], skeletal malformations [18,19] reproductive botch $[12,15,18,20-24]$ anatomical mutilation in the gills [17,25-27] and [12] and death [28,29,14,30,31,16]. Amplified an acidity initiated the drop in plasma sodium and chloride and death begin in fishes exposed to an acidic surroundings $[32,33]$ stated that the $\mathrm{O} 2$ carrying capacity of fish blood in vitro, fallen abruptly below pH7. The partial pressure of oxygen $\left(_{\mathrm{p}} \mathrm{O}\right)$ of trout blood declined in acute acid exposure [34-36,12], and found a lessened capability to extract $\mathrm{O} 2$ from water of low $\mathrm{pH}$. [37] reported that brook trout got reduction in blood $\mathrm{pH}$ when they were exposed to acid waters. In response to long-term acid exposure, the haematocrit, haemoglobin values of blood and haemopoietic activity of fish are all elevated, presumably to uphold $\mathrm{O}_{2}$ carrying ability $[38,39,12]$. Effect of lethal and sublethal acidic $\mathrm{pH}$ medium on Oxygen (02) consumption and metabolism in Oreochromis mossambicus [12], brook trout (Salvelinus fontinalis) were reported by $[40,20]$ reported that low $\mathrm{pH}$ also disturbed the normal action of choriolytic enzymes in embryos 
of the European perch, [41] reported that the female white suckers from acidified lakes did not release eggs, because of the inactivity of the females to maintain the serum calcium level. Low pH prevents the spawning in some species of fish $[42,43]$ reported that reproduction was impaired in blunt nose minnows. Hatching failure has also been reported $[44,45]$ has done preliminary work on the effect of low $\mathrm{pH}$ and behavioural changes in Sarotherodon mossambicus.

\section{Materials and methods}

The $\mathrm{pH}$ of the experimental freshwater (control) has gradually reduced into $\mathrm{pH} 6.6,5.8$ and 5.0 by adding $5 \%$ Sulfuric acid $\left(\mathrm{H}_{2} \mathrm{So}_{4}\right)$, The prepared $\mathrm{pH}$ experimental media has stirred well by electric stirrer and the $\mathrm{pH}$ was measured perfectly with a digital $\mathrm{pH}$ meter and frequently test with a pen $\mathrm{pH}$ meter, and ascertained the constant $\mathrm{pH}$ without the fluctuations. Cyprinus Carpio were used for histopathological studies. They were exposed to different acidic environmental media ( $\mathrm{pH}$ 5.0, 5.8, 6.6 and 7.2) for 21 days. Care was taken to observe that all the fishes introduced to each aquarium (20 L capacity), were alive throughout the experimental term. Four fishes were introduced in every aquarium and triplicated manner. Fishes were fed with chopped beef. Fresh test acid media were prepared daily and the experimental fishes were introduced. After exposure for 21 days, the test fish were sacrificed to get the necessary tissues for histological studies. The organs chosen for the present study were gill, liver and intestine. Tissues from these organs of the control and exposed fish were excised from live fish and processed for observations.

\section{Tissue processing}

The tissues included in this study were gills, liver and intestine. The tissues were fixed in Zenker's fluid, for 6 to 8 hours. The fixed tissues were washed in running tap water overnight and then dehydrated in ascending grades of isopropyl alcohol. Finally the tissues were completely dehydrated through two changes of $100 \%$ alcohol for 20 to 30 minutes in each. The tissues were, then, dealcoholized by two changes of xylol, 20 to 30 minutes in each change. It was followed by infiltration in xylol saturated with paraffin wax of congealing point $56^{\circ}$ to $58^{\circ} \mathrm{C}$. The tissues were left in molten wax for at least 30 minutes in the embedding bath. In order to remove all the clearing agent (xylol) three changes in paraffin were made for through infiltration. The tissues were embedded in labelled paper 'boats' after proper orientation of the processed tissues. The whole process of embedding was made after Weesner (1968). The embedded tissues were sectioned at 7 $\mathrm{mm}$ (microns) thickness in a rotary microtome. The ribbon of sections was cut into strips and floated in warm water which was poured over acid leaned glass slides. The ribbons were then pasted with a thin film of fixative. Egg albumen and Haupt's fixative were used. Flattening of the sections was achieved by floating the sections on water medium, which was warmed only to the extent required to spread the sections. Neutral formalin ( $2 \%)$ was used as a floating medium for the sections when Haupt's fixative was used. When the sections became flat and well-spread, the water was drained. After complete air drying for a few hours, the slides were left overnight on slide warmer whose temperature was maintained 10 to $15{ }^{\circ} \mathrm{C}$ below the melting point of the paraffin wax. The sections were deparaffinised in xylene and rehydrated in descending grades of iso-propyl alcohol. The tissues fixed in mercuric chloride containing fixative were passed through $70 \%$ alcohol with $0.5 \%$ iodine to remove the mercury precipitate present in the tissues. Further, rehydration was carried out by bringing the sections to distilled water and the sections were left for 3 minutes in $5 \%$ sodium thiosulphate solution to remove the iodine. Later the sections were washed in running tap water for 5 minutes. The slides for Histological and Histopathological observations were stained using one of the following staining methods:

\section{Staining-dichrome staining}

Ehrlich's haematoxylin is a stain which is commonly used in histopathological examination. It is highly suitable for nuclear staining. The cytoplasmic stain is eosin Y $(0.2 \%)$, Ehrlich's hematoxylin used to stain the tissue sections. The slides were washed in purified water then they were subjected in to staining procedures, the staining time is approximately 900 seconds (15 minutes), The over stained segments were then distinguished in $1 \% \mathrm{Hcl}$ in water. After rinsing in $\mathrm{Hcl}$, the sections were, coloured blue in tap water and again observed by microscopic methods. This procedure was recurrent over till the nuclei and basophil cytoplasm was correctly distinguished and the cytoplasmic surroundings were colourless. Then, the sections were splashed in flowing tap water for 60 minutes to eliminate the aluminium ammonium sulphate. After splashing in distilled water, the sections were counter stained in $0.2 \%$ Eosin $\mathrm{Y}$ for 15 seconds. In order to remove the excess of Eosin $\mathrm{Y}$, the slides were rinsed in distilled water and quickly kept in $95 \%$ alcohol. They were finally placed in $100 \%$ alcohol I and II, for 5 minutes in each solution and passed through xylol I and II. Sections were, then, astride in DPX [46].

\section{Results}

\section{Normal histology}

Gills: The rachis of gill from which the individual filaments of gills arise has a core of the cartilaginous skeleton covered by a connective tissue sheath. Many layers of cells are arranged around the core. The cell layers from the parts of the gill, the outermost layer is the gill epithelium (Figure 1), the connective tissue and epithelial cells in several layers envelopes the rachis. The outer most epithelial layer forms the respiratory surface of each finger shaped gill filament. Their epithelial cells are mostly isodiametric and in certain places they are cuboidal. The epithelial cells have large nuclei. The mucus cells are goblet shaped and their vacuole like cavities are filled with mucus.

\section{Histopathological changes}

C.carpio when exposed to $\mathrm{pH} 6.6$ media revealed the epithelial necrosis and cellular edema (Figure 2), when exposed to $\mathrm{pH} 5.8$ experimental media, they exhibited extensive gill damage with epithelia capillary separation, the epithelial lining showed severe destruction and there was a hypertrophy of the mucocytes which project on the epithelial surface. The 
cells showed desquamation. But the severity of acid stress was evident by the formation of mucus hyperplasia, with heavy deposition of mucus on gills (Figure 3), when exposed to $\mathrm{pH} 5.0$ experimental media exhibited destruction of the epithelial layer. Figure 4 illustrates epithelial destruction with degenerative desquamation, hypertrophy (Figure 4) of the mucocytes and hyperplasia of undifferentiated cells. The most prominent feature was degeneration of surface epithelial cells and severe epithelial hyperplasia. The entire architecture of gills were ruptured (Figure 4) resulting in the development of Necrotic gill disease (NGD).

Normal histology of the intestine: The intestine is a long tubular structure. In sectional view it exhibits a very simple histological organization (Figure 5). The innermost lining layer is mucosa consisting of epithelial cells. There is a laminapropria consisting of connective tissue occupying the narrow spaces between the glands and muscularis mucosa. The normal villi show mucosa, submucosa, muscularis and serosa. The mucosa comprises of a layer of epithelial cells establishing the covering of lumen. The submucosa entails of connective tissue. The outermost layer is muscularis coat. The mucosal epithelium entails of columnar cells with basal nuclei, they form a spherical shrill layer of the intestinal wall.

Histopathological changes; The experimental fishes, when exposed to $\mathrm{pH} 6.6$ revealed the chronic inflammation of laminapropria, which led to a massive accumulation of macrophages, necrosis and atrophy of the intestinal villi (Figure 6), when exposed to $\mathrm{pH} 5.8$ experimental media exhibited, the hyper vacuolations of intestinal mucus membrane, mucosal necrosis of absorptive cells and submucosal edema. (Figure 7). C.carpio exposed to $\mathrm{pH} 5.0$ test media showed (Figure 8) massive sloughing off mucosal epithelium and accumulation of macrophages.

Normal Histology of the liver: Liver cells of $C$. carpio are grouped into lobules. The rows of hepatocytes form laminae. Small bile ducts also find their place in the interlobular connective tissue. The hepatocytes are almost isodiametric and polygonal. The hepatocytes have basiphili cytoplasm and are uninucleated (Figure 9). The nuclei are very prominent in the hepatocytes. Sinusoids are seen and vacuoles are rarely found.

Histopathological changes: Acid stressed (pH 6.6) C.carpio's liver shown the abnormal histopathological marks of deformed hepatocytes, necrotic debris and macrophages (Figure 10). Exposure of C.carpio in pH 5.8 showed the massive and intense granulomatous reaction, death and debris of cells, aggregates of granular materials and necrotic hepatitis (Figure 11). When C. carpio were exposed to the same acidic environment ( $\mathrm{pH}$ 5.0) they showed the development of necrotic hepatitis (Figure 12).

\section{Discussion}

Though the environmental acidification is a global problem report on the effect of low $\mathrm{pH}$ has been focused on temperate fishes, particularly brook trout $10 ; 39 ; 6 ; 65 ; 48 ; 64$ $[47,48,49,25,27,50]$, rainbow trout $78[51]$, fathead minnows 39 [48] and Atlantic salmon 23 [17]. The morphology and ultrastructure of the gills have been well reviewed by 38 [52].

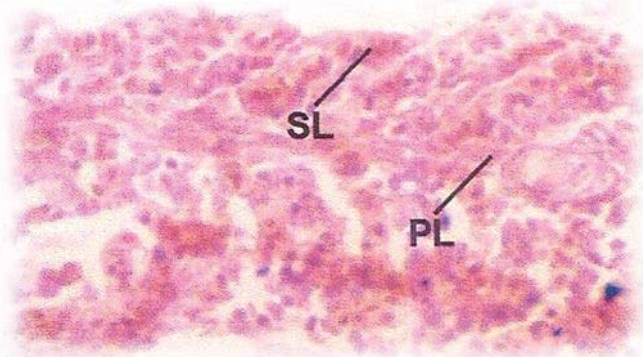

Figure 1: Gills of control fish Cyprinus carpio showing normal primary lamellae (PL) with series of flat leaf like secondary lamellae (SL). Eosin hematoxylin ( $x$ 400).

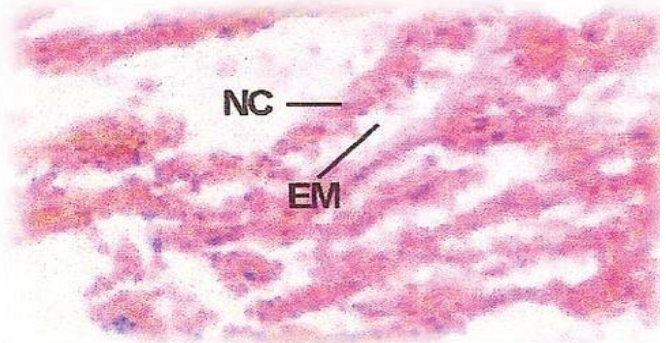

Figure 2: Gills of Cyprinus carpio exposed to pH 6.6 showing Epithelial Necrosis (NC) with marked cellular edema (EM). Eosin hematoxylin ( $x$ 400).

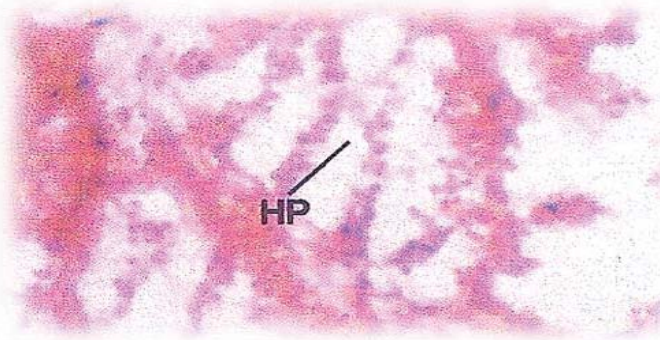

Figure 3: Gills of Cyprinus carpio exposed to pH 5.8 showing the mucus hyperplasia (HP)with heavy deposition of mucus on the gills are visible. Eosin hematoxylin (x 400).

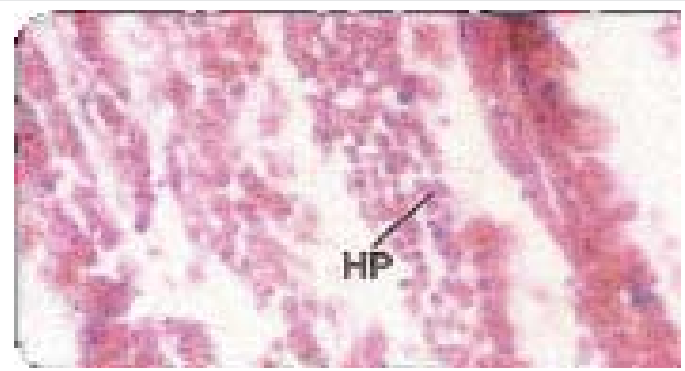

Figure 4: Gills of Cyprinus carpio exposed to $\mathrm{pH} 5.0$ showing the degeneration of surface epithelial cells; epithelial hyperplasia (HP) and formation of Necrotic Gil Disease (NGD) Eosin hematoxylin (x 400).

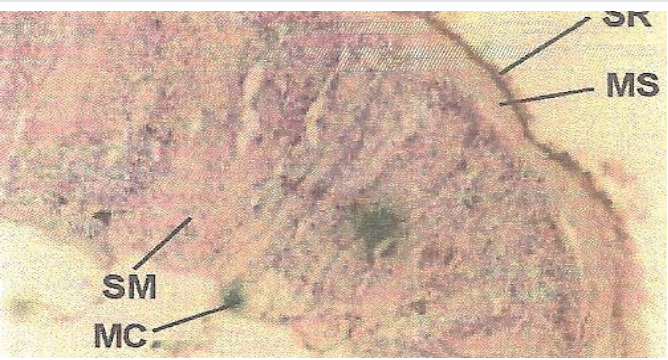

Figure 5: Intestine of control fish Cyprinus carpio showing normal mucosa (MC), submucosa (SM), muscularis (MS) and serosa (SR) Eosin hematoxylin ( $\mathrm{x} 400)$. 


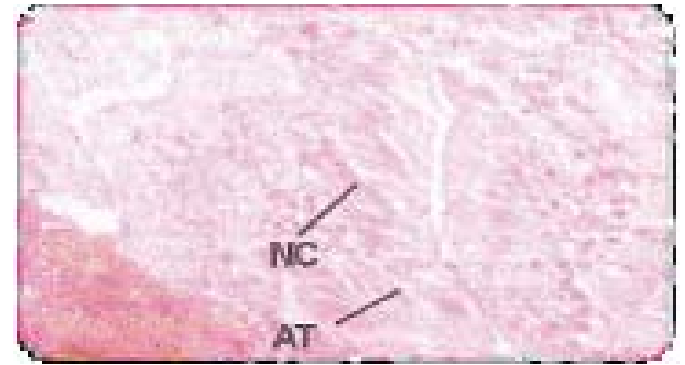

Figure 6: Intestine of C.carpio exposed to $\mathrm{pH} 6.6$ showing Necrosis (NC) and atrophy (AT) of intestinal villi, Eosin hematoxylin $(x 400)$
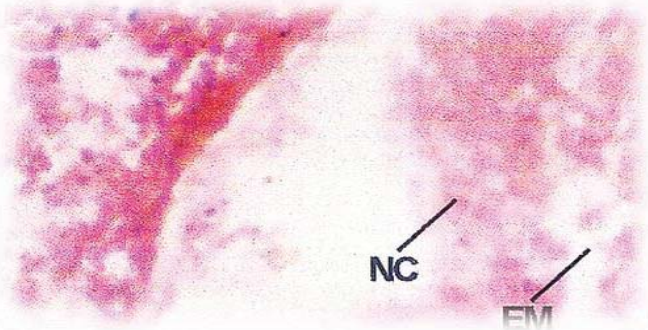

Figure 7: Intestine of C.carpio exposed to $\mathrm{pH} 5.8$ showing obvious mucosal necrosis (NC) and submucosal edema (EM) Eosin hematoxylin ( $x 400)$

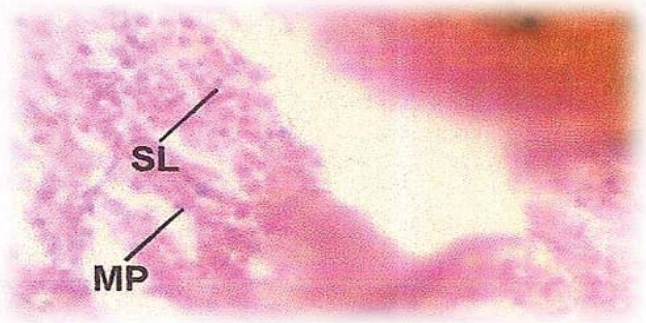

Figure 8: Intestine of C.carpio exposed to pH 5.0 showing massive sloughing off (SL) mucosal epithelium and accumulation of macrophages (MP) Eosin hematoxylin ( $x 400)$.

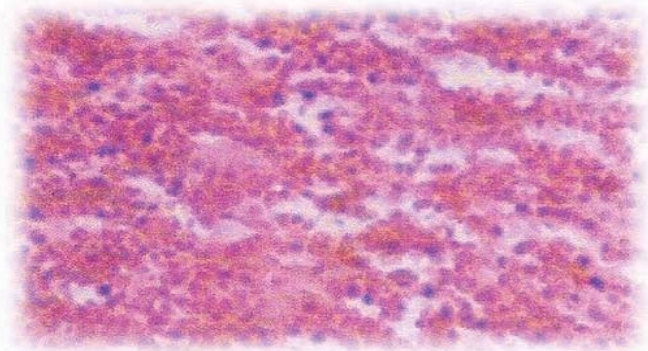

Figure 9: Liver of the control fish Cyprinus carpio showing the normal liver parenchyma. Eosin haematoxylin (x 1000).

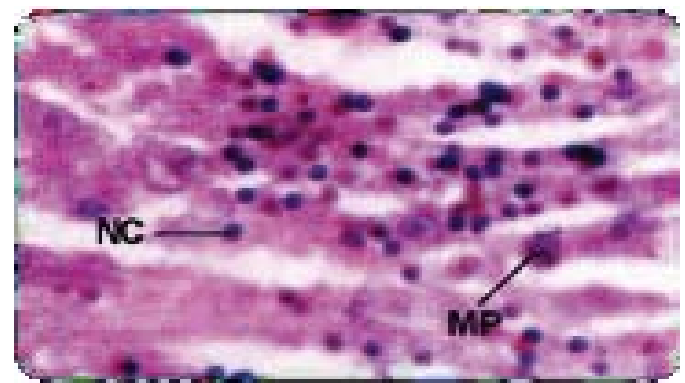

Figure 10: Liver of fish Cyprinus carpio exposed to $\mathrm{pH} 6.6$ showing deformed hepatocytes, granular degeneration of hepatocytes (HC); areas of necrotic debris (NC) and macrophage (MP) aggregates are visible. Eosin haematoxylin ( $x$ 1000)

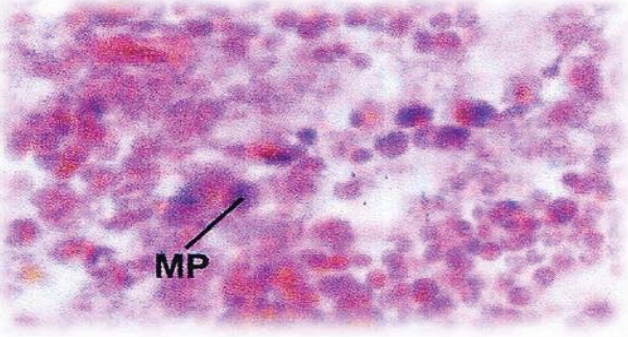

Figure 11: Liver of fish exposed to $\mathrm{pH} 5.8$ showing hepatocellular degeneration and necrosis, note the development of the disease necrotic hepatitis; Eosin haematoxylin (x1000)

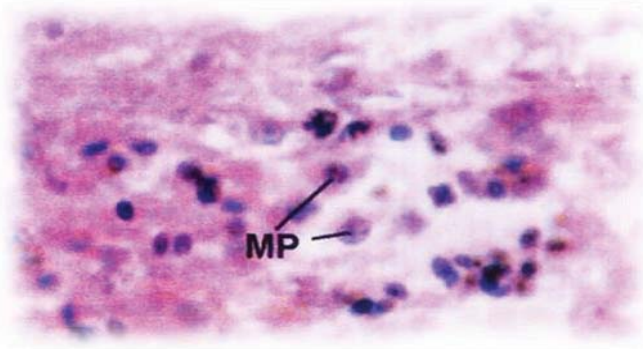

Figure 12: Liver of fish exposed to $\mathrm{pH} 5.0$ showing severe necrotic hepatitis with macrophage (MP) aggregates are visible; Eosin haematoxylin (x1000).

\section{Gills}

The structure of normal gills have been reported in rainbow trout [53,54,55]; striped mullet [56], lamprey [57], brook trout [27], Atlantic salmon [58,17]; Aplocheilus lineatum [59] and Tilapia [12]. Acidic trauma severely impinges the gill, intestine and liver morphology and architecture of the fish in the present investigation. C.carpio when exposed to the acidic environments showed the transfigures of gills such as, epithelial necrosis, epithelial corrosion or destruction, extensive gill damage with epithelio- capillary separation and severe epithelial destruction with degenerative desquamation, mucus hyperplasia, heavy deposition of mucus on gills, epithelial hyperplasia and developmnt of disease called necrotic gill disease (NGD). The results of the present histopathological studies corroborated with the aggravation of gill destruction by lowering the $\mathrm{pH}$ of water to less than $\mathrm{pH} 5.0$ as reported by [60]. Supportive evidences were also given by Ibrahim [12] who stated the similar effects in Oreochromis mossambicus exposed at $\mathrm{pH}$ 5.0. [11], who reported hypertrophy of mucus cells, excessive mucus secretion and separation of epithelial layer in the gills of brook trout and hypertrophy necrosis of cells in gills of Atlantic salmon; [37] stated elevated mucus secretion at gills; $[61,62]$ have reported hypertrophy of mucus cells and hyper secretion in brook trout; [58] described the presence of brownish mucus on gills and body in Sunpee trout and [27] recounted the necrotic and degenerating cells in the gills of brook trout. Likewise, [17] also testified morphological mutilation to the gills with impairment being more sombre at low $\mathrm{pH}$. Results obtained in the present investigation force the author of the experiment to suggest that $C$. carpio is showing higher sensitivity to low $\mathrm{pH}$. [63] also suggested the $\mathrm{pH}$ sensitivity of $C$. carpio. The lesions on the gills and the occurrence of mucus might have disturbed the gill respiration as reported 
[12]. The gill is the principal target organ and death results from a combination of ionoregulatory, osmoregualatory and respiratory dysfunction $[60,64,12]$.

\section{Intestine}

Intestinal pathology also believed to be a very sensitive indicator of acid stress in fishes. C.carpio exposed to different acidic exposures to $\mathrm{pH}$ 6.6, 5.8 and 5.0 exhibited the disruption in the intestinal morphology. C.carpio, under various degrees of acidic stress revealed the formation of necrosis and atrophy of intestinal villi, sub mucosal edema and mucosal necrosis and the massive destruction of the mucosal epithelium. As there are no accessible research findings on the histopathological vicissitudes in the fish intestine exposed to acidic waters, the author of the contemporaneous exploration could not associate the present results with the related publications. However, the comparison was made with the pathological changes attained in the intestinal tissues of fishes exposed to other environmental toxicants. Histopathological changes revealed by the acid stressed ( $\mathrm{pH} 6.6,5.8$ and 5.0), C.carpio exhibited the formation of necrosis and atrophy of the intestinal villi, submucosal edema and mucosal necrosis and massive destruction of the mucosal epithelium. The results of the present observations corroborated well with the results reported by [12] in Oreochromis mossambicus, [65] in Scylla serrata when exposed to higher concentrations of heavy metals, [66] in Sarotherodon mossambicus exposed to mercury and [67] in Puntius sarana exposed to malathion. [68] Have also reported similar changes in Oreochromis mossambicus intoxicated with sublethal exposures of phosphomidan and [59] in Aplocheilus lineatum when exposed to effluents from the coconut husk retting pit. Disruption of histological organization in the organ systems reduced the output of enzymes and consequently impairment of digestive and absorptive process and their physiological efficiencies.

\section{Liver}

The vertebrate liver has an outstanding role to play in the physiology and wellbeing of the organisms. In addition to taking part in digestion, it serves in storing glycogen and performing most of the anabolic functions. Detoxification is one of the vital roles of the liver. It is testified that smooth endoplasmic reticulum is involved in detoxifying poisonous constituents entering the systems. Maiming to hepatic parenchymal tissue has been the most often stated pathological effect on fishes exposed to various chemical agents $[69,70,71,72]$. Pollution which has a harmful effect on the organism leaves indelible marks on the structure of the liver and its functioning. The present observations showed that the acidic stress effectively affected the liver tissues of $C$. carpio. The results of the histopathological examination of acid stressed C.carpio exhibited the formation of vacuolations in hepatocytes and the formation of necrotic hepatitis (NH). The fallouts of the present observations corroborated well with the results reported by [12] in Oreochromis mossambicus were exposed to different acidic $\mathrm{pH},[73$ ] in Heteropneustes fossilis when exposed to textile mill effluent; [74] in Notopterus notopterus exposed to phenolic compounds; [68] in Oreochromis mossambicus when exposed to phosphomidan for $120 \mathrm{hrs,} \mathrm{[75]} \mathrm{in} \mathrm{Lebistes} \mathrm{reticulates}$ exposed to toxicity of zinc and cadmium for two months [59] in Aplocheilus lineatum exposed to coconut coir retting effluents. Many marks of widespread cellular worsening ensued all over the body. An organ, specifically affected is liver. This happens mainly because of the absence of adequate nutrients to upkeep the normal high rate of metabolism in the liver cells, but also partly because of the dangerous vascular exposure of the liver cells to any toxic or other metabolic influence in jolt or stress. Amid the detrimental cellular effects that are known to occur in most body tissues lessening of active transport of sodium and potassium through the cell membrane is noteworthy. As an outcome of sodium and chloride accretion in cells, potassium is vanished from the cells. In addition, cells instigate to swell and mitochondrial bustle in the liver cells as well as in many other tissues of the body becomes sternly dejected. Lysosomes begin to split open tissues with the intracellular release of hydrolase that cause further intracellular deterioration. Cellular metabolism of nutrients such as glucose ultimately befits significantly depressed in the last stages of shock. The accomplishments of some hormones are depressed as well, including as much as 200 fold depression in the action of insulin. All these effects contribute to further deterioration of many organs of the body, including the liver with depression of its many metabolic and detoxification functions [76]. The Liver is the principal of intercessor metabolism and when it was affected, the entire physiological coordination is abnormal. Finally the $\mathrm{pH}$ of the water is very important for the normal growth and development of the fishes, the acidic $\mathrm{pH}$ will affect the total physiology of the fishes, especially the growth, nutritive components, metabolism, Hematology and Histology of the fishes [12]; It will lead to the disappearance of the fish species [12]; Aquatic acidification, both freshwater and ocean are the serious global issue; it will affect production of fishes, the aquatic resources and aquaculture practices.

\section{References}

1. Van der Oost R, Beyer J, Vermeulen NP (2003) Fish bioaccumulation and biomarkers in environmental risk assessment: A review. Environ Toxicol Pharmacol 13: 57-149. Link: https://bit.ly/2wA9cFD

2. Gernhofer M, Pawet M, Schramm M, Müller E, Triebskorn R (2001) Ultrastructural biomarkers as tools to characterize the health status of fish in contaminated streams. Journal of Aquatic Ecosystem. Stress and Recovery 8 : 241-260. Link: https://bit.ly/2VmJVrO

3. Winkaler EU, Silva AG, Galindo HC, Martinez CBR (2001) Biomarcadores histológicos e fisiológicos para o monitoramento da saúde de peixes de ribeirões de Londrina, Estado do Paraná. Acta Scientiarum 23: 507-514 Link: https://bit.ly/2V4JbHY

4. Fanta E, Rios FS, Romão S, Vianna, Freiberger S (2003) Histopathology of the fish Corydoras paleatus contaminated with sublethal levels of organophosphorus in water and food. Ecotoxicol Environ Saf 54: 119-130. Link: https://bit.ly/34wYDQd

5. Schwaiger J, Wanke R, Adam S, Pawert M, Honnen W (1997) The use of histopathological indicators to evaluate contaminant-related stress in fish J Aquatic Ecosystem Stress Recovery 6: 75- 86. Link: https://bit.ly/2ybR31c

6. Ortiz-Delgado JB, Segner H, Arellano JM, Sarasquete C (2007) Histopathologica alterations, EROD activity, CYP1A protein and biliary metabolites in gilthead seabream Sparus aurata exposed to Benzo (a) pyrene. Histol Histopathol. 22 417-432. Link: https://bit.ly/2V530z1 
7. Mount DR, Swanson MJ (1990) Responses of brook trout (Salvelinus fontinalis) fry to fluctuating acid, aluminium and low calcium exposure. Can J Fish Aquat Science 47: 1623-1630. Link: https://bit.ly/2V3B1zH

8. Beamish RJ, Harvey HH (1972) Acidification of Lacoche mountain lakes, Ontario and resulting fish mortalities. J Fish Res Board Can 29: 1131-1143.

9. Mount DI (1973) Chronic effect of low pH of fathead minnow survival, growth and reproduction. Water Res 7: 987-93. Link: https://bit.ly/3ceHxcq

10. Trojnar JR (1977) Egg and larval survival of white sucker (Catostomus commersoni) at low pH. J Fish Res Board Can 34: 262-266.

11. Daye $P$, Garside $E$ (1980) Structural alterations in embryos and alevins of the Atlantic salmon, Salmo salar L., induced by continuous or short term exposure to acidic levels of pH. Canadian J Zool 58: 27-43. Link: https://bit.ly/2XuRL4o

12. Ibrahim A (2003) Investigation on the effect of environmental acidification (low pH) on the eco-physiology of fishes, Ph.D. thesis, 2003, Manonmanium Sundaranar University, India.

13. Gjedrem T (1980) Growth and survival of fingerlings in acidic water. In: SNSF Project Sandef Jord. Norway 309.

14. Lacorix GL, Gordon DJ, Johnson DL (1987) Effects of low pH on the survival, growth an ionic composition of post-emergent Atlantic salmon (Salmo salar) Can J Fish Aquat Sci 42: 768-775. Link: https://bit.ly/3ceGmtO

15. Cleveland L (1989) Chronic no observed effect concentrations of Al for brook trout exposed to low calcium, dilute acidic water. In : Environmental Chemistry and Toxicology of Aluminium edited by T. E. Lewis publishers. Inc. Chelsea $1989 ; 229-246$

16. Baker JP (1990) NAPAP Report 13. National Acid precipitation Assessment program. Acid deposition, state of the science and technology. II.

17. Hamilton J, Haines TA (1995) Influence of fluoride on aluminium toxicity to Atlantic Salmon (Salmo salar). Can J Fish Aquat Sci 52: 2432-2444. Link https://bit.ly/3cjEujv

18. Duis K, Oberemm A (2000) Survival and sublethal response of early life stages of pike exposed to low $\mathrm{pH}$ in artificial post-mining lake water. J Fish Biology 57: 597-613. Link: https://bit.ly/3aaENvz

19. BeamishRK(1974)Growthand survivalof whitesuckers Catostomuscommerson in an acidified lake. J Fisheries Research Board of Canada 31: 49-54. Link: https://bit.ly/34ARyhx

20. Peterson RH, Daye PG, Metcalfe JL. Inhibition of Atlantic salmon (Salmo salar) hatching at low pH. Can J Fish Aquat Sci 37: 770-774. Link: https://bit.ly/3b5keld

21. Haya K, Waiwood BA (1981) Acid, $\mathrm{pH}$ and chorionase activity of Atlantic salmon (Salmo salar) eggs. Bull Environ Contam Toxicol 27: 7-12. Link: https://bit. ly/2yWOC4Y

22. Cleveland L, Little EE, Hamilton SJ, Buckler DR, Honn JB (1986) Interactive toxicity of $\mathrm{Al}$ and acidity to early life stages of brook trout. Trans. Am Fish Soc 115: 610-620. Link: https://bit.ly/3b36Dul

23. Mills KH, Chalanchok SM, Mohr LC, Davies IJ (1987) Responses of fish populations in lake 223 to and years of experimental acidification. Can J Fish Aquat Sci 44 : 114-125. Link: https://bit.ly/3eguCbL

24. Rasmussen G, Hansen G (1994) Influence of ohre and acidication on the survival and hatching of brown trout eggs (Salmo trutta). In : Sublethal and chronic effects of pollutants in fresh water fish (Muller R, Lyod R. eds.) 196 210. Oxford. Black well.

25. Chevalier G, Gauther L, Moreau G (1985) Histopathological and electron microscopic studies of gills of brook trout (S. fontinals) from acidified lakes. Can J Zool 63: 2062-2070. Link: https://bit.ly/2Xyeuwq

26. Jagoe $\mathrm{CH}$, Haines TA, Buckler DA (1987) Abnormal gill development in Atlantic salmon (Salmo salar) fry exposed to aluminium at low pH. Annal Soc R Zoo Belg 117 (suppl.1): 375-387.

27. Muller DA, Sanchez DA, Bergman HL, Mc Donald DG, Rhem RG, et al. (1991) Nature and time course of acclimation to aluminium in juvenile brook trout (Salvelinus fontinalis). Gill Histology Can J Fish Aquat Sci 48 : 2016-2027. Link: https://bit.ly/2xnokqc

28. Freeman HC, Salang GB (1985) The effects of an acid river, caused by acid rain, on weight gain. Steroid genesis and reproduction in the Atlantic salmon (Salmo salar). Aquatic Toxicology and Society for testing and materials, Philadelphia, PA 339-349.

29. Lacorix GL (1985) Effects of low environmental pH on survival growth and ionic composition of post emergent Atlantic salmon. Can J Fish Aquat Sci 43 768-775. Link: https://bit.ly/2JXpjAc

30. Watt WD (1987) A summary of the effects of acid rain on Atlantic salmon (Salmo salar) in Canada. Water Air Soil Pollut 35: 27-35. Link: https://bit.ly/2Vnoy8W

31. McKee MJ, Knowles CO, Buckler DR (1989) Effects of Al on biochemical composition of Atlantic salmon. Arch Environ Contam Toxicol 19: 101-118. Link: https://bit.ly/34vAMQY

32. Muniz IP, Leivestad H (1980) Acidification-effects on freshwater fish. Proceedings of the International Conference on the Ecological Impacts of Acid Precipitation, eds Drabløs D \& Tollan A. Oslo. Norway: SNSF project 84-92.

33. Green AAm Root RW (1933) The equilibrium between haemoglobin and oxygen in blood of certain fishes. Biol Bull 64 : 383-404. Link: https://bit.ly/34ASp1J

34. Wiebe AH, Mc Gavrock AM, Fuller AC, Markus HC (1934) The ability of fish to extract oxygen at different hydrogen ion concentrations. Physiol Zool 7 435-488. Link: https://bit.ly/3ci5ShL

35. Townsend LD, Cheyne $H$ (1944) The influence of hydrogen ion concentrations on the minimum dissolved oxygen toleration of silver salmon Oncorhynchus kisutch. Ecology 25: 461-466. Link: https://bit.ly/3efujhu

36. Vaala SS, Mitchell RB (1970) Blood oxygen tension changes in acid expressed brown trout. Penn Aqua Sci 41-44

37. Packer RK, Dunson WA (1972) Anoxia and sodium loss associated with the death of brook trout at low pH. Comp Biochem Physiol A Comp Physiol 41 : 17-26. Link: https://bit.ly/3a7VFmq

38. Nevile CM (1979) Sub lethal effects of environmental acidification on rainbow trout (Salmo gairdneri) J Fish Res Board Can 36: 84-87. Link: https://bit.ly/3celD8k

39. Fromm PA (1980) Review of some physiological and Toxicological responses of fresh water fish to acid stress. Environmental Biology of Fishes 5: 79-93. Link: https://bit.ly/2V6jgzQ

40. Roseland B (1980) Physiological responses to acid water in fish. Drablos and Tollan 348-349.

41. Beamish R (1976) Acidification of lakes in Canada by acid precipitation and the resulting effects on fishes. Water Air and Soil Pollution 1976; 6: 501-504. Link: https://bit.ly/2K1/1rK

42. Johnson D, Webster D (1977) Avoidance of low pH in selection of spawning sites by brook trout Salvelinus fontinalis. J Fish Res Board of Canada 34 2215-2218. Link: https://bit.ly/34x9lkg

43. Horning W, Neiheisel T (1979) Chronic effect of copper on the blunt nose minnow Pimephales notatus (Ratinesque). Arc Environ Con Toxicol 8: 545552

44. Runn PM, Johansson N, Milbrink G (1977) Some effects of low pH on the hatchability of eggs of Perch Perca fluviatilis L Zoon 5: 115-125.

45. Salate Rengithabai U (1988) Effect of low pH on the feeding energetics and respiratory metabolism of Sarotheordran mossambicus M.Phil. Thesis Madurai Kamarajar University, India

Citation: Ibrahim A, Narayanan M, Salman K, Mohamed S (2020) The effect of freshwater acidification in the tissues of Cyprinus carpio. Glob J Zool 5(1): 009-015. DOI: https://dx.doi.org/10.17352/gjz.000014 
46. Frances WM (1960) General zoological microtechniques; Huntington Publisher, N.Y. USA. Link: https://bit.ly/2VnvuTB

47. Daye PG, Garside ET (1976) Histopathologic changes in surficial tissue of brook trout. Salvelinus fontinalis (Mitchill), exposed to acute and chronic levels of pH. Can J Zool 54: 2140-2155. Link: https://bit.ly/3ebDWON

48. Leino R, Mc Cormick (1984) Morphological and morphometrical changes in chloride cells of the gill of Pimephates promeals after chronic exposure to acid waters. Cell Tissue Res 236: 121-128.

49. Tietge JE, Johnson RD, Bergman HL (1988) Morphometric changes in gill secondary lamellae of brook trout (Salvelinus fontinalis) after long term exposure to acid and aluminium. Can J Fish Aquat Sci 45: 1643-1648. Link: https://bit.ly/3egUtQS

50. Smith TR, Haines TA (1995) Mortality, growth, swimming activity and gill morphology of brook trout Salvelinus fontinalis and Atlantic salmon (Salmo salar) exposed to low pH with and without aluminium. Environ Pollu 90: 33-40. Link: https://bit.ly/2K2mpKo

51. Youson J, Neville C (1980) Deposition of aluminium in gill epithelium of rainbow trout (Salmo gairdneri Richardson) subjected to sublethal concentrations of heavy metal. Can J Zool 65: 647-656. Link: https://bit.ly/3bgCDvL

52. Laurnet P, Dunnel S (1980) Morphology of gill epithelia in fish. Ame J Physiol 238: R 147-R 159. Link: https://bit.ly/2XwlYjq

53. Olson R, Fromm P (1973) A scanning electron microscope study of secondary lamellae and chloride cells of rainbow trout (Salmo gairdneri). Z Zellforsch Mikrosk Anat 143: 439-449. Link: https://bit.ly/2wEU89W

54. Huges GM (1976) Respiratory responses to hypoxia in fish. Am Zool 13: 474 489. Link: https://bit.ly/2VmOuSa

55. Kendall M, Dale J (1979) Scanning and transmission electron microscopic observations of rainbow trout (Salmo gairdneri) gill. J Fish Res Board Can 36 1072-1079. Link: https://bit.ly/2wz88lo

56. Hosler FE, Ruby JR, Mc Ilwain TD (1979) The gill arch of the mullet Mugil cephalus. I. surface ultrastructure. J Experimental Zoology. 1979; 208: 379 398. Link: https://bit.ly/34uRkIZ

57. Lewis SV, Potter IC (1976) A scanning electron microscope study of gills of lamprey Lampetra fluvitalis (L). Micron 7: 205-211. Link: https://bit.ly/2XCCgrn

58. Jagoe CH, Haines TA (1983) Alternations in gill epithelial morphology of yearling sunpee trout exposed to acute acid stress. Trans Am Fish Soc 112 659-695. Link: https://bit.ly/2VmOCRE

59. Madaswamy S (2001) Ecophysiology of a chosen freshwater fish Aplocheilus lineatum (Valenciennes) Ph. D. Thesis MS. University, India. Link: https://bit.ly/3b5cxeJ

60. Exley C, Chappell JS, Birchall JD (1991) A mechanism for acute aluminum toxicity in fish. J Theor Biol 151: 417-428. Link: https://bit.ly/2Vnwg2X

61. Westfall BA (1945) Coagulation film anoxia in fishes. Ecology 26: 283-287. Link: https://bit.ly/2Xre4rM

62. Ultsch GR, Gros G (1979) Mucus as a diffusion barrier to oxygen: possible role in $\mathrm{O} 2$ up take at low $\mathrm{pH}$ in carp (Cyprinus carpio) gills. Comparative Biochemistry and physiology 62: 685-689. Link: https://bit.ly/2Xs4qVT

63. Schaperclaus (1991) Fish disease. Published by Gulab Primalani Oxonian Press Pvt. Ltd. New Delhi.

64. Wood CM (1989) The physiological problems of fish in acid waters. In Acid toxicity and Aquatic animals (Morns R, Taylor EW, Brown DJA, Brown JA) Cambridge university press 125-152. Link: https://bit.ly/2JWEolw

65. Narayanan KR (1989) Toxicity studies on the estuarine portunid crab Scylla serrata (Forskal); Ph. D. Thesis, Annamalai University. 155

66. Naidu KA, Akkilandar KA, Ramamurthi R (1982) Histopathological studies in liver and intestine tissue of Sarotheordan mossambicus in response to mercury toxicity. Proc. An India Symp. on Physiol. Response of animal to pollution. Link: https://bit.ly/2JYX303

67. Moitra A, Lal R (1989) Effect of sublethal doses of malathion and BHC on the intestine of the fish Puntius sarana. Environ Ecol 7: 412-414.

68. Indira N, Ramkumar P, Meenakshi V (1999) Histopathological lesions in Oreochromis mossambicus subjected to acute phosphomidn toxicity, sustainable environment, 1999 ed (N. Sukumaran) 196-201.

69. Couch JA (1975) Histopathological effects of pesticides and related chemicals on the livers of fish; In: The pathology of fishes edited by Ribelin WE, Migaki G. University of Wisconsin Press, Madison. 559-584. L:

70. Johnson DW (1968) Pesticides and fishes-A review of selected literature. Trans Am Fish Soc 97: 398-424. Link: https://bit.ly/2XCDfYB

71. Mc Kim J, Benoit (1971) Effects of long-term exposures to copper on survival growth and reproduction of brook trout (Salvelinus fontinalis). J Fish Res Board Can 28: 655-662.

72. Tucker RK, Leitzke JS (1979) Comparative toxicology of insecticides for vertebrate wild life and fish. J Pharmacol Ther 6: 167-220. Link: https://bit.ly/2RvVJpA

73. Murugesan AG (1988) Toxicity of textile mills effluent to an air breathing fish. Ph.D. Thesis. Madurai Kamaraj University. India.

74. Gupta, Saraj, Dalela RC (1986) Liver damage in Notopterus notopterus following exposure to phenolic compounds. J Environ Biol 7: 75-80.

75. Aravind S, Sharma MS (1995) Acute and chronic toxicity of zinc and cadmium to some developmental stages of Lebistes reticulates (Peters). Poll. Res14 $83-92$.

76. Guyton AC (1986) Textbook of medical physiology. 7th edi. Saunders co. Philadelphia PA.

77. Beamish RJ (1972) Lethal pH for white sucker Catostomus commenson (Lacepede). Trans Am Fish Soc 101: 355. Link: https://bit.ly/2RxxozM

78. Dunson WA, Martin RR (1980) Survival of brook trout in bog derived acidity gradient. Ecology 54: 1370-1376. Link: https://bit.ly/2Rxxx6i

79. Lacorix GL (1989) Ecological and physiological response of Atlantic salmon in acidic organic rivers of Nova scotia, Canada. Water Air Soil Pollut 48: 375-386. Link: https://bit.ly/2V3qUe3

Copyright: () 2020 Ibrahim A, et al. This is an open-access article distributed under the terms of the Creative Commons Attribution License, which permits unrestricted use, distribution, and reproduction in any medium, provided the original author and source are credited. 